EGU21-7495

https://doi.org/10.5194/egusphere-egu21-7495

EGU General Assembly 2021

(c) Author(s) 2021. This work is distributed under

the Creative Commons Attribution 4.0 License.

\title{
Effect of artificial recharge on submarine groundwater discharge: a Belgian case study
}

\author{
Marieke Paepen, Kristine Walraevens, and Thomas Hermans \\ Ghent University, Geology, Ghent, Belgium (marieke.paepen@ugent.be)
}

The Belgian coastal phreatic aquifer is mostly characterized by salty/brackish pore water at shallow depth. The eolian dunes delimiting the sandy beach are one of the few locations where fresh potable water can be found. The drinking water demand of the coastal region is putting high pressure on these water resources, especially during the touristic summer season. Also, the dryer summers that were faced over the last years increase the need for solutions.

At Oostduinkerke, the Intercommunale Waterleidingsmaatschappij van Veurne-Ambacht (IWVA) combines the pumping of groundwater in the dunes with artificial surface (since 2002) and underground recharge (since 2014) for more sustainable exploitation. The infiltrating water is treated effluent from a nearby sewage treatment plant (Aquafin, Wulpen). The recharge in the dunes reduces the risk of attracting salty/brackish water from the North Sea and the lower lying polder area in the South and allows for more stable groundwater levels, especially around the infiltration lake.

To assess the efficiency of the managed aquifer recharge project, we collected electrical resistivity tomography (ERT) data offshore, on the beach, and part of the dunes. Marine continuous resistivity profiling (CRP) were performed during both low and high tide. The latter provide a good overlap with the land ERT. The profiles were collected in front of the IWVA site, as well as, to the west and east, to assess the lateral variation of the salt-freshwater distribution in the aquifer. Based on the electrical resistivity distribution, we are able to identify the patterns of submarine groundwater discharge (SGD) and saltwater intrusion in the study area.

The infiltration of treated wastewater directly affects the piezometric levels of the surrounding area. Before the exploitation started in the dunes (1947), the natural freshwater heads were higher west of the infiltration area, due to the presence of a shallow clay layer (Vandenbohede et al., 2008). The higher hydraulic heads are also seen on recent groundwater models (Lebbe, 2017), but despite the larger hydraulic gradient in the West, the pore water resistivity seems to be higher in front of the IWVA site based on our data. Also, the zone of discharge is found below the low water line in front of the infiltration site, while it is seen on the beach to the west and east. We can assume that the SGD flux is largest in front of the recharge site (Paepen et al., 2020). Therefore, SGD seems to be enhanced by artificial recharge in this area. Further research is needed to validate this. 
Lebbe, L. (2017). Grondwatermodel van de geplande wijzigingen in waterwinning Sint-André. Opdrachtgever: Intercommunale Waterleidingsmaatschappij van Veurne Ambacht (IWVA).

Paepen, M., Hanssens, D., Smedt, P. D., Walraevens, K., \& Hermans, T. (2020). Combining resistivity and frequency domain electromagnetic methods to investigate submarine groundwater discharge in the littoral zone. Hydrology and Earth System Sciences, 24(7), 3539-3555.

Vandenbohede, A., Van Houtte, E., \& Lebbe, L. (2009). Sustainable groundwater extraction in coastal areas: a Belgian example. Environmental Geology, 57(4): 735-747. 